\title{
studia
}

\section{Teoria sztuk plastycznych u Ortegi y Gasseta}

Skupiając uwagę na estetyce hiszpańskiej, łatwo zauważyć, jak zmienne były jej losy. Silnie rozwijana w XVIII wieku, w wieku XIX przestała niemal istnieć $^{1}$, by w następnym stuleciu zainteresowania filozofów znów skoncentrowały się na jej problemach. Zmiany następowały powoli. Nowe koncepcje estetyczne pojawiły się najpierw w Katalonii, a później w całej Hiszpanii. Ważnym estetykiem, którego echa twórczości można znaleźć w pracach José Ortegi y Gasseta był José Maria Sanchez de Muniain. Podejmując refleksję nad naturą piękna, wymienił on trzy jego charakterystyczne cechy: wolność, rozumianą jako wolność intelektu do rozpoznawania piękna i intensyfikacji doświadczenia, szczęśliwość powstająca w kontakcie wyobraźni z przedmiotami pięknymi oraz humanizm pojmowany jako jedność woli i moralności². Koncepcję humanizmu hiszpański myśliciel najszerzej omówił w publikacji zatytułowanej Estetyka pejzażu naturalnego, pozostającej pod wyraźnym wpływem neotomizmu. Odwołując się do podstawowych cech fenomenu piękna w ujęciu świętego Tomasza: jasności, jedności, niepodzielności i porządku filozof analizuje percepcję pejzażu w wymiarze ogólnym. Najważniejszą rolę pełni dla niego kolor, niebo, postać, jeżeli jest obecna, ruch, ukazanie życia, wielkość. Na tej podstawie dochodzi do wniosku, że pejzaż jako gatu-

\footnotetext{
1 A. Guy, Historia de la filozofia española, Barcelona 1985, s. 448.

2 Tamże, s. 450.
} 
nek malarski czy fotograficzny wywołuje w oglądającym doznanie intelektualne.

Filozof Francesco Mirabent z Barcelony, który w swej rozprawie doktorskiej zajmował się XVIII-wieczną estetyką angielską, w swoim monumentalnym dziele zatytułowanym $O$ pięknie podejmuje próbę zdefiniowania przywołanego w tytule zjawiska. Nie oznacza to, że uznaje je za w pełni poznawalne. Autor, podkreśla, zawsze kryje w sobie zagadkę. Twierdzi, że na tzw. aktywność estetyczną mają wpływ różnorakie czynniki. Jednym z nich są nasze aktualne akty poznawcze lub myśli, czy też dotychczas przeżyte doświadczenia artystyczne. Aktywność estetyczna składa się z gustu oraz intuicji. W koncepcji tej wartości estetyczne implikują moralność, w której zbiegają się: natura i sztuka, pozostające w stanie nieustannej gry. Dzięki pięknu możemy żyć w wyższych stanach świadomości.

Koncentrując się na analizie pism Ortegi y Gasseta, należy wymienić kilka istotnych, zastosowanych przez filozofa pojęć. Przede wszystkim będzie to pojęcie dzieła sztuki z jednej strony tradycyjnego, a z drugiej już współczesnego. Tradycyjnym dziełem sztuki są np. obrazy Goi czy Velazqueza, którym Ortega y Gasset poświęcał w swoich rozmyślaniach dużo miejsca ${ }^{3}$. Analizując zachowane teksty filozofa, można wyróżnić kilka sfer, które analizował właściwie aż do śmierci, zdając sobie sprawę, że analizy tej nie doprowadzi do końca. Jak pisał:

[...] cechą charakterystyczną problemu sztuki jest jej nierozwiązywalność. Chociaż jest to problem nie do rozwiązania, to jednak człowiek stara się go zgłębić, wydzielając różne jego aspekty, a każda dziedzina sztuki jest wyrazem pewnego autentycznego aspektu problemu ogólnego ${ }^{4}$.

Starając się zgłębić problem istoty dzieła sztuki, wyróżnił kilka jego aspektów, do których się później odwoływał. Po pierwsze, skupił uwagę na życiu artysty, analizował fenomen jego twórczości, odnosząc go do czasów, w których tworzył, używając jako materiału porównawczego dzieł współczesnych mu malarzy i literatów. Zdawał sobie też sprawę z faktu, że gdy na przykład chodzi o Velazqueza i jego twórczość w tym aspekcie wiele jeszcze pozostało do przebadania:

${ }^{3}$ J. Ortega y Gasset, Velazquez i Goya, Warszawa 1993, s. 5

${ }^{4}$ Tenże, Adam w raju, [w:] tegoż, Dehumanizacja sztuki i inne eseje, przeł. P. Niklewicz, wybrał i wstępem opatrzył S. Cichowicz, Warszawa 1980, s. 53. 
[...] jestem przeświadczony, że ani o Velazquezie, ani o nikim innym nie powiedziano tego, co najistotniejsze, co najprawdziwsze, co przystawałoby do naszej gruzłowatej rzeczywistości jak rękawiczka do dłoni ${ }^{5}$.

Jako historyk sztuki Ortega analizuje spotkania różnych artystów oraz wpływ tych spotkań na późniejszą twórczość. O Velazquezie pisał:

Większy wpływ wywarło spotkanie z Rubensem, które pozwoliło artyście wyzwolić się duchowo i przerwać otoczkę prowincjonalizmu spowijającą życie Hiszpanii $[\ldots]^{6}$.

W dalszej kolejności poddaje analizie poszczególne dziedziny malarstwa, jakimi zajmował się artysta, poczynając od portretu poprzez martwą naturę aż do pejzażu. W tym miejscu Ortega podejmuje refleksję nie tylko nad istotą stylu malarza, ale także samego malarstwa:

Celowo przypominam, że malarstwo jest zajęciem czysto ludzkim i nie powstaje samorzutnie na murze jako plama lub zaciek ani też nie wykwita na płótnie niczym wysypka. Malarstwo nie jest zarazem sposobem bycia ścian ani płócien, ale pewnych ludzi, którzy je praktykują ${ }^{7}$.

Dla Gasseta przy rozważaniu fenomenu malarstwa istotny jest nie tylko jego społeczny i kulturowy odbiór tu i teraz (współcześnie), ale przede wszystkim kwestia, jak odbierane było ono w momencie powstania. „Malarska rzeczywistość to nie sam obraz, ale także to wszystko, co się wokół

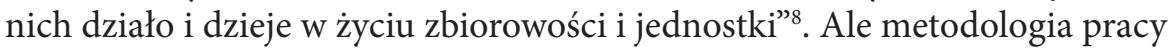
Ortegi nie ogranicza się jedynie do analizy biografii. W esejach poświęconych Velazquezowi czy Goi filozof wyjaśnia fenomen i zjawiskowość hiszpańskiej sztuki, podejmując psychologiczny problem geniuszu twórców9. Dużo czasu poświęca analizie stylu i treści, wpisując różne nowo powstałe zjawiska w ogólny rozwój malarstwa europejskiego ${ }^{10}$. Można wywnioskować, że przyporządkowuje rozwój malarstwa do tła epoki, w jakiej tworzyli artyści.

\footnotetext{
${ }^{5}$ Tamże, Velazquez i Goya, Warszawa 1993, s. 79.

6 Tamże, s. 15.

7 Tamże, s. 53.

${ }^{8}$ Tamże, s. 127.

${ }^{9}$ Na temat Goi: tamże, s. 264-272.

10 Tamże, s. 65.
} 
Cofa się do czasów XVI- i XVII-wiecznej Hiszpanii, by wprowadzić czytelnika w niedostępny dla niego świat. Posługuje się przy tym metodą hermeneutyczną. Jak sam pisze: „[...] jej istota polega na uściślaniu słowa poprzez kontekst, w jakim się ono pojawia"11. Celem takiej metody jest, według Ortegi, odkrywanie pełnej rzeczywistości, „prawdziwej całości”" a środkiem do celu, jak wyżej pisałem, ma być analiza stylistyczna i fenomenologiczna, podparta analizą historyczno-społeczną czasów, w których artyści tworzyli. Umieszczając dzieła w kontekście konkretnego okresu, stosuje pojęcie realności, którego używa do wykreślenia ogólnego horyzontu analizy.

W jednym z wykładów, przeznaczonych dla studentów, formułuje cztery tezy związane z dziejowością malarstwa i stanowiące narzędzia metody historycznej. Po pierwsze, działalność człowieka i następstwa, jakie są z tym związane, traktuje jako poszczególne fakty, które da się powiązać z uniwersum i dzięki temu poddać interpretacji. Ale intencją autora jest nie tylko łączenie ze sobą poszczególnych związanych z interesującym go zagadnieniem faktów, co czynią historycy. Celem jego metody staje się łączenie owych faktów z ogólnym bytem. Poprzez byt autor rozumiał całość, w którą wplecione były jej części, czyli w tym wypadku owe fakty. Całość lub, jak pisał, circunstancia, to także okoliczność, przez którą rozumie się nie tylko sumę kształtujących konkretną ludzką istotę dziejowości. Ortega zdawał sobie sprawę, że malarz, poeta lub filozof jest w stanie wykroczyć poza tak pojmowaną okoliczność i stworzyć dzieło o charakterze uniwersalnym (w sensie transhistorycznym). „Oto, co powinien malować malarz - wieczne warunki żywotności czynili najśmielsi malarze"13. Świadomość tego faktu umożliwia rozumienie fenomenu artystycznego, określanego jako hiszpańskie szkoły malarskie. Błędem historyków było natomiast powołanie do życia pojęcia tzw. szkoły hiszpańskiej. Ortega stoi na stanowisku, że prawidłowo rozumiane pojęcie „szkoły” może zostać odniesione jedynie do szkoły włoskiej. Jako jedyna jest ona bowiem samoistna, substancjalna i samowystarczalna. „Do końca XVI wieku nie ma w sztuce innej samowystarczalnej i niezawisłej rzeczywistości niż malarstwo włoskie"14. Zdaniem Ortegi nie wystarczy mówić o szkole, powołując się wyłącznie na określone cechy dzieł sztuki, techniki, środki artystyczne itp. Szkoła malarska zawsze musi być postrzegana jako wynik procesu histo-

\footnotetext{
11 Tamże, s. 83.

12 Tamże, s. 85.

${ }^{13}$ Tenże, Adam w raju, s. 71.

${ }^{14}$ Tenże, Velazquez i Goya, s. 85.
} 
rycznego oraz działalność wybitnych osobowości, które są w stanie czerpać jedynie ze swojego źródła, zapewniając mu równocześnie dalszy rozwój. Ów rozwój oczywiście przejawia określone cechy. O niektórych z nich już napisałem. Chodzi tu przede wszystkim o powolny rozwój, który będzie przejawiał się wpływem dawnego stylu na nowe tereny oraz wyodrębnieniem centrum, w którym się ów styl narodził. Za przykład po raz kolejny może posłużyć malarstwo włoskie, które od czasów quattrocenta podbijało wciąż nowe „tereny”, by pełnię rozwoju uzyskać w wieku XV, chyląc się potem ku upadkowi.

W ten sposób malarstwo włoskie kończy się we Flandrii wraz z Rubensem, Fransem Halsem, Van Dyckiem, Rembrandtem [...] w Hiszpanii z Zurbaranem, Velazquezem i Murillem ${ }^{15}$.

Analizując powyższy proces historycznie, można dojść do wniosku, że w okresie, gdy we Włoszech malarstwo zaczęło obumierać, w Hiszpanii zaczął się jego rozwój. Problem stylu i jego rozwoju to kolejna kwestia, jaką podejmuje Ortega. Filozof dokonuje rozróżnienia form naturalnych i artystycznych. Pierwsze wypływają z naturalnego wyglądu przedmiotów, które artysta przetwarza na swój specyficzny sposób, zgodnie z własnym temperamentem lub upodobaniami, tworząc $\mathrm{w}$ ten sposób sztukę. „Sztuką nie są przedmioty poza obrazem, ale styl, w jakim na obrazie się je przedstawia"16. Oznacza to, że intencją artysty, czy tego chce, czy nie zawsze, jest zmiana otaczającej go rzeczywistości. Według Ortegi impulsu do takiej zmiany może dostarczyć nawet znudzenie otoczeniem, zmęczenie nim, co prowadzi do tzw. odrzeczywistnienia. Taką sztukę reprezentował Velazquez czy Ribera. Ich geniusz polega na tym, że rzeczy wyrywają oni z ich naturalnego statusu, nadając im nowy wyraz.

Znakomity malarz umieszcza w swych obrazach nie tylko rzeczy, które chciał, czy które wygodnie mu było skopiować, lecz umieszcza w nich również niewyczerpany świat bodźców pobudzających te rzeczy do życia wiecznego, do nieskończonej wymiany dóbr ${ }^{17}$.

Do rozbudowanego systemu pojęciowego związanego z dziełem sztuki zalicza się także pojęcia: materiału, obrazu oraz formy, natomiast do grupy

\footnotetext{
15 Tamże, s. 111.

16 Tamże.

${ }^{17}$ Tenże, Adam $w$ raju, s. 71.
} 
związanej z wartością artystyczną takie pojęcia, jak: styl, maniera, wrażliwość czy metafora. Osobnym zagadnieniem będzie sens takich pojęć, jak: artystyczna wolność tworzenia nowych form, aktualność dzieła sztuki czy relacja twórca-odbiorca. Na koniec chciałbym przytoczyć fragment, w którym Gasset dobitnie dał wyraz specyfice swej myśli na gruncie kultury hiszpańskiej:

Przerzucając ostatnio kartki antologii poezji współczesnej zatytułowanej Biesiada poetów, zauważyłem, że mój sposób widzenia spraw uniwersalnych, narodowych i osobistych jest akurat odwrotny od tego, jaki daje się zauważyć u wszystkich współczesnych poetów ${ }^{18}$.

Według Ortegi w życiu codziennym człowiek ustawicznie narażony jest na przeżycia okropne i enigmatyczne. Nękają go problemy, których charakter $\mathrm{z}$ jednej strony pozostaje intelektualny, a z drugiej jawi się jako codzienny i realny ${ }^{19}$. Artysta, jak i filozof są konstruktorami, którzy dzięki swym zdolnościom dostrzegania wartości tworzą światy integralne, wewnętrznie zamknięte. Ich zadaniem jest „zbudowanie systemu przekonań popartych rozmaitymi dowodami” ${ }^{20}$. Dokonać tego można jedynie przez oczyszczenie umysłu z legend, które nie są relacjami między ideami. Wszystko to możliwe jest tylko przez użycie czystego rozumu. Tezę, do której Ortega próbuje przekonać czytelnika, wyjaśnia na przykładzie Velazqueza i Kartezjusza. Obaj w swoim czasie doprowadzili świat do głębokiej przemiany. Velazquez zerwał z tradycyjnym rozumieniem malarstwa i na przekór wartościom obecnym w jego czasach sprowadził je do czystej wizualności ${ }^{21}$. Plama barwna, szybkie pociągnięcie pędzla służą mu jedynie do przedstawienia idei. W początkach swojej twórczości zainteresowany był przede wszystkim płaszczyzną odbijającą światło. Dlatego wzrok kogoś, kto ogląda jego dzieła, skupia się przede wszystkim na powierzchni przedmiotów. Przedmiot nie jest już czymś, co buduje kompozycję. Prymat wiedzie jego lśniący blask, on sam stwarza jedynie pretekst do ukazania go na płótnie ${ }^{22}$. Fenomen Kartezjusza

\footnotetext{
${ }^{18}$ Tenże, Krytyka barbarzyństwa, [w:] tegoż, Dehumanizacja sztuki, s. 35.

${ }^{19}$ Szerzej na ten temat: Alonso, Rafael, El naufrago ilusionado. La estetica de Jose Ortga y Gasset, wyd. Siglo XXI, Madryt 1997, s. 166-177.

${ }^{20}$ J. Ortega y Gasset, Velazquez i Goya, s. 47-48.

${ }^{21}$ Tamże, s. 47: Nikt spośród obecnych mu artystów nie czuł podobnie, a przynajmniej nie z taka sama ostrością. Powinniśmy zatem sobie wyobrazić Velazqueza jako kogoś, kto w dramatycznej samotności przeżywa własna sztukę, na przekór wszystkim wartościom triumfującym w jego czasach.

${ }^{22}$ Tenże, O punkcie widzenia w sztuce, [w:] tegoż, Dehumanizacja sztuki, s. 249.
} 
polegał na sprowadzeniu myślenia do kryteriów racjonalnych, podobnie więc jak Velazquez - Kartezjusz „zwraca się przeciw intelektualnym zasadom panującym w jego czasach"23. Występuje przeciw scholastykom oraz Grekom, czyli przeciw dominującej w jego czasach wielkiej tradycji. Formalizm, jaki proponowali scholastycy, uznaje za nieprzyswajalny i dlatego zadaniem jednostki staje się w jego wykładni budowanie nowego systemu przekonań. Ktoś, kto jest filozofem, powinien jeszcze mieć dodatkową zdolność do kontemplacji wszystkich stron bytu, a dzięki temu być specjalistą od uniwersów. Odkrywa on nasz byt w świecie. W przeciwieństwie do tego artysta tworzy byty irrealne, światy iluzoryczne, pracuje poza realnością. Odwołując się do przykładu malarstwa, Gasset pisze, że realność w obrazie jest jego realnością, a nie realnością rzeczy kopiowanej. Geniusz Velazqueza polega na tym, że jako pierwszy w swoich czasach posiadł umiejętność namalowania w stanie ruchu rzeczy, które na tradycyjnych obrazach były przedstawiane jako usytuowane „zawsze na swoim miejscu” 24 . Artysta maluje przedmioty nie jako bryły wyizolowane $\mathrm{w}$ przestrzeni, ale ściśle przez tę przestrzeń określone, w zwyczajowych miejscach. Dokonuje tego, koncentrując się zwłaszcza na światłocieniu, który umożliwia uzyskanie wrażenia trójwymiarowości malowanego obiektu, co stanowi w budowie całej kompozycji istotny element ${ }^{25}$. Geniusz artysty pozwala mu na tworzenie w przestrzeni ciał przedmiotów nieruchomych i spokojnych, których specyficzną cechą jest to, że potrafią na sobie zatrzymać źrenicę obserwatora. W dalszej kolejności Ortega poświęca uwagę poszczególnym elementom kompozycji, które istotnie określają jej istotę, pogłębiając podziw dla geniuszu twórcy. Główną cechą charakteru emanującą z przedstawionych $\mathrm{w}$ jego obrazach postaci jest wdzięczność, której źródłem nie jest wyłącznie projekcja wyobraźni widza, lecz stanowi wyraźnie efekt celowego oddziaływania na tę wyobraźnię odpowiednimi środkami artystycznymi. Ale ta poetyckość dzieła, której nie należy mylić z powabem, nie jest wynikiem „założeń formalnych"26, jej korzenie stanowią samą rzeczywistość, a ściślej umiejętność jej dostrzegania, dającą się przełożyć na środki artystyczne umożliwiające wyrażenie, poprzez wartości estetyczne, wybranego w sposób celowy stanu psychologicznego. W dalszej części swych rozmyślań Ortega uznaje, że charakterystyczna dla dzieł Vela-

\footnotetext{
${ }^{23}$ Tamże.

${ }^{24}$ Tenże, Adam w raju, s. 52.

${ }^{25}$ Tenże, O punkcie widzenia w sztuce, s. 248.

${ }^{26}$ Tenże, Velazquez i Goya, s. 50.
} 
zqueza wytworność gestów czy też powab jest cechą specyficzną dla narodu hiszpańskiego. Jak pisze:

Jest to właśnie ów rys hiszpański, jaki ludzie Północy odnajdują w postaciach Velazqueza, to, co najpiękniej określa ich wdzięk. [...] Lud hiszpański na wszystkich szczeblach drabiny społecznej ma dar wdzięcznego poruszania się: mamy więc wytworność grandów i urok kobiety z gminu oraz toreadora tańczącego ze śmiercią. Jak każdy dar owa zdolność ciała do rytmicznego poruszania się jest formą kultury mającą swój początek i pewną linię rozwojową, krótko mówiąc własną historię ${ }^{27}$.

Efektem zabiegów, jakie stosował Velazquez, jest według Ortegi emanujący z jego dzieł spokój. To bardzo ciekawe zjawisko estetyczne, gdyż nie taki bywał z reguły zamiar artystów barokowych. Najczęściej dążyli oni do eskalacji w wyobraźni widza stanu napięcia. Efekty światłocieniowe, przestrzenna kumulacja postaci, kompozycje diagonalne, wszystko to miało powodować w wyobraźni odbiorcy wzrost niepokoju. Inaczej było u Velazqueza, który $\mathrm{w}$ swoich obrazach zawiera odmienną ideę dynamiki. Postacie na swoich płótnach utrwala tak, by niczym migawką aparatu utrwalić je w charakterystycznej chwilowości bycia tu oto. Malarze klasycznego baroku z reguły postępowali inaczej. Celem Rubensa czy El Greca też stawało się wprawdzie wplecenie w treść obrazu zjawiska ruchu, ale nie towarzyszyła temu ambicja do oddania owego specyficznego fenomenu jednostkowego momentu czy stanu. Chodziło im tylko o przedstawienie ciągu chwil bez ich wyodrębnienia.

W koncepcji Ortegi problem ruchu pełni w ogóle istotną rolę, gdy chodzi ogólnie o kwestie związane z przemianą stylu w sztuce zachodnioeuropejskiej $^{28}$. Dynamika, pisze filozof, jest prostą zasadą, rządzącą ewolucją sztuki europejskiej od czasów Giotta. Można dostrzec wyraźne analogie, jakie zachodziły między szkołami malarstwa zachodniego a uprawianą w czasach ich rozkwitu filozofią (zob. wspomniane porównanie Velazqueza i Kartezjusza). Każdy obraz można oczywiście interpretować na różne sposoby, jednak czymś, co pozostaje w nim niezatarte i co może być dokładnie określone, to "piętno miejsca pochodzenia” ${ }^{29}$. Można określić miejsce jego powstania

\footnotetext{
27 Tamże.

${ }^{28}$ Tenże, O punkcie widzenia w sztuce, s. 238.

${ }^{29}$ Tamże.
} 
i pochodzenie, dokładnie odnieść do technik i ideologii konkretnych szkół. Ale te istotne fakty mogą zostać rozmyte w zależności od naszej znajomości malarstwa oraz, co ważniejsze, od optycznej jakości, jaką posługiwał się malarz.

Życie człowieka, takie jakie dała mu natura, to życie w stanie surowym, które jako życie ludzkie pozostaje niedokonane. Dzięki konstytuującej roli kultury zostaje ono wypełnione nowymi charakterystycznymi treściami. Człowiek kultury jest zobligowany do ciągłego podejmowania decyzji, dzięki czemu tworzy swój własny wyalienowany ze świata natury byt. Ortega zrywa z przekonaniem, że identyfikację faktu bycia człowiekiem można sprowadzać wyłącznie do problemu ciała, duszy czy świadomości. Ortega zwraca uwagę na egzystencjalny wymiar ludzkiej istoty. Stwierdza krótko: człowiek jest dramatem. Dramat zaś w jego rozumieniu rozgrywa się w nas i wokół nas nieustannie i jako taki przytrafia się każdemu z osobna. Nie ma więc możliwości ominięcia dramatyzmu życia jednostki. Każdy z nas może jedynie nieustannie dokonywać wyborów między różnymi alternatywami. Niezbędnym środkiem określającym ową dramatyczność ludzkiego losu jest więc dialektyka. Kumuluje się ona w formie alternatywy między jego aktualnym doświadczeniem a doświadczeniem przeszłości (poszczególne etapy w życiu człowieka są nieodwracalne).

Jako byt konstytuujący się w czasie ludzka istota nie ma możliwości zawrócenia swego losu. Dlatego w koncepcji Ortegi tak ważne miejsce zajmuje historia, której poznanie umożliwia prawidłowe rozumienie sytuacji (w liczbie mnogiej) jednostki czy narodu. W jednym z esejów filozof pisze wprost, że historia powinna być pojmowana jak film ${ }^{30}$. Można przez to rozumieć, że nie jest statycznym stanem konstytuującym się w wyobraźni jej badacza. Kolejno postępujące po sobie kadry przywołanego w powyższej analogii filmu nie pozostają bez związku. Następują po sobie, wynikając jedne z drugich.

Prawdziwą rzeczywistością historyczną nie jest data, zdarzenie czy rzecz, lecz ewolucja, w której składniki te stapiają się i płyną wszystkie razem. Historia nabiera rozpędu, z bezwładu rodzi się dynamizm ${ }^{31}$.

Jako byt zanurzony w swej przeszłości człowiek ma jednak zdolność do jej przekraczania:

\footnotetext{
30 Tamże.

31 Tamże.
} 
Przeszłość jest nieodwracalna, przeszłością są zarówno wszelkie ludzkie czyny, jak i dzieła, które zostały już stworzone przez żyjącego artystę ${ }^{32}$.

Ale ludzka istota, co oczywiste, nie może w pełni przewidzieć następstwa wydarzeń. Jest w stanie tylko przekraczać swój byt i wykraczać poza siebie, to znaczy poza swoje dotychczasowe doświadczenia. Jeden ze sposobów owego wykraczania ${ }^{33}$ poza swoją własną egzystencję stanowi kontakt $\mathrm{z}$ innym człowiekiem, dokonujący się w określonych okolicznościach. Fenomen, jakim jest dzieło sztuki, ma zdolność do narzucania na naszą wyobraźnię swojej tylko dla siebie charakterystycznej formy. Oznacza to, że owa forma, zgodna z występującymi w naturze własnościami odwzorowywanego obiektu lub nie, służy przede wszystkim ekspresji, a ekspresja jest „królestwem duszy”"

Ortega wyróżnia w tym miejscu tzw. obecność sąsiednią rzeczy, których elementy materialne w sztukach wizualnych stają się sobie podległe. Charakterystycznym elementem każdego obiektu artystycznego jest, według Ortegi, jego forma. Ale nie jest to oczywiście jedyny ważny element:

Każde dzieło może być jedynie realizacją pewnego wachlarza wartości estetycznych, siłą rzeczy odrzucając inne. Nie istnieje jedno malarstwo, jedna rzeźba czy jedna poezja ${ }^{35}$.

Spośród najważniejszych cech dzieła sztuki Ortega wymienia jego wieczność (w sensie „ponadczasowość", a nie nieskończoność chronologiczna). Kryterium wieczności staje się ciągła aktualność dzieła sztuki. Oznacza to, że tylko przez bezustanne zainteresowanie określonym dziełem sztuki można sprawić, by trwało wiecznie. Jego ciągłej aktualności dopatrywał się filozof w formie, którą dzieło prezentuje. Analizując dokładniej rozprawy Ortegi dotyczące szeroko pojętej problematyki dzieła sztuki, można natrafić na określenie „wieczność wewnętrzna”. Kryterium wyznaczającego sens tego nowatorskiego pojęcia doszukuje się filozof w ciągłej aktualizacji dzieła, czego przykładem może być właśnie malarstwo Velazqueza. Tylko dzięki ciągłości relacji, jaka zachodzi między dziełem sztuki a odbiorcą, można mówić o wieczności, zawartej w owym dziele cesze. Analiza sztuki klasycznej zostaje wzbogacona u Ortegi również o refleksje dotyczące sztuki współczesnej. Jej

\footnotetext{
32 Tamże, s. 238.

${ }^{33}$ U Husserla, Jaspersa, Heideggera, Sartre’a owo wykraczanie zwie się transcendowaniem.

${ }^{34}$ J. Ortega y Gasset, Żywotność, dusza, duch, [w:] tegoż, Dehumanizacja sztuki, s. 211.

${ }^{35}$ Tenże, O krytyce artystycznej, [w:] tegoż, Dehumanizacja sztuki, s. 261.
} 
fenomen sprowadza się do kilku charakterystycznych elementów. Refleksje Ortegi na ten temat są oparte przede wszystkim na obserwacji różnorodnych zjawisk społecznych oraz reakcji społeczeństwa na fenomen nowej sztuki, która narodziła się na przełomie XIX i XX wieku. Według naszego filozofa styl sztuki XIX wieku w sygnalizowanym czasie wyczerpał się, realizm jako styl stracił swe pierwotne znaczenie, artyści, mówiąc kolokwialnie, stali się bezpłodni. Sztuka nie mogła być odtąd jedynie procesem kopiowania rzeczywistości. Jego współczesną postawę charakteryzuje więc odwrót od naocznej rzeczywistości, a działalność artysty zmierza ku niszczeniu aspektów humanistycznych. W dalszej kolejności twórcy pozbawiają sztukę elementów wartości pozaestetycznych (etycznych, politycznych, historycznych itd.).

Nie oznacza to, że proces dehumanizacji zaczął się na przełomie XIX i XX wieku. A według Ortegi stylizacja, jaką posługiwali się wówczas artyści, stała się początkiem procesu, który doprowadził do całkowitego wyzbycia się w niektórych prądach sztuki awangardowej tzw. elementów ludzkich. Delikatne zmiany, jakie wprowadzono w malarstwie XIX wieku, polegające na uproszczeniu formy czy wprowadzeniu nowych elementów w pejzażu lub portrecie, doprowadziły do odwrotu od, by użyć języka fenomenologii, rzeczywistości naocznej. Spowodowało to również przemiany w dziedzinie aktu percepcji dzieła. Zetknięcie odbiorcy ze sztuką współczesną może powodować, co oczywiste, jedną z dwóch dychotomicznych reakcji: afirmację lub odrzucenie. Odrzucenie bardzo często spowodowane jest porzuceniem wartości artystycznych i estetycznych lub historycznych obecnych w sztuce wcześniejszej, takich jak: wątki realistyczne, naturalistyczne czy romantyczne. Sztuka współczesna wymagając od odbiorcy specyficznej wrażliwości i kompetencji, staje się dla niego niezrozumiała. W konsekwencji można powiedzieć, że wręcz dochodzi do podziału społeczeństwa na tych, którzy nową sztukę rozumieją, i są mniejszością, oraz na tych, którzy nie są w stanie jej zrozumiećs ${ }^{36}$.

Realizm jako kierunek wszechstronnie obecny w sztuce XIX wieku zaangażowany w losy swoich bohaterów, i przeznaczony dla mieszczaństwa, stał się nawykiem, co prowadziło do sytuacji, że nowa sztuka odrzucająca często wszelkie przesłanie humanistyczne przestała być zrozumiała. Postawę artysty XIX-wiecznego często charakteryzowało jeszcze głębokie zaangażowanie w wartości kultury mieszczańskiej. Bohaterami obrazów byli też nierzadko

${ }^{36}$ Szerzej na temat relacji między arystokracją i masą: R. Gaj, Ortega y Gasset, Warszawa 2007, s. 251. 
zwykli mieszczanie, którzy oglądając dzieła, stawali się ich uczestnikami. Zadowolenie estetyczne sprowadzało się zaś głównie do uprzytomnienia sobie podświadomie uznanej za swoją, obecności w treści dzieła. Sztuka, a zwłaszcza malarstwo, nie miało ani umoralniać, ani nauczać. Efektem takiej wizji przesłania sztuki staje się, zdaniem Ortegi, ubóstwo wartości artystycznych oraz estetycznych. Sztuka miała tu jedynie odwzorowywać codzienność, na którą składają się troski oraz radości życia. Jakiekolwiek przygotowanie widza do odbioru nie było potrzebne. Dychotomiczny podział na tych, którzy rozumieją nową sztukę, i tych, którzy jej nie pojmują, wywołuje, w opinii Ortegi, istotne konsekwencje społeczne. Nowa sztuka nie pociąga już mas, ci, którzy jej nie rozumieją, pozostają w większości. Dlatego jej popularność gwałtownie spadła.

Widocznie nowa sztuka nie jest przeznaczona dla każdego. Lecz jedynie dla specjalnie wybranej mniejszości. Stąd też bierze się oburzenie, jakie budzi wśród mas. Ktoś, komu się dzieło sztuki nie podoba, chociaż je rozumie, czuje się wyższy ponad nie i nie ma powodów do oburzenia ${ }^{37}$.

Z jednej strony powoduje to brak przygotowania do odbioru, a $\mathrm{z}$ drugiej zmiany zachodzące we wrażliwości artystów. W konsekwencji nowa sztuka jest przeznaczona dla nielicznych. Tylko wybrani spośród społeczeństwa są w stanie zrozumieć jej przesłanie. W opinii Ortegi jednym z zadań tak pojmowanej sztuki staje się rozszczepianie społeczeństwa, innym - powoływanie do życia nowych światów.

Nowa sztuka już przez samo swoje istnienie zmusza przeciętnego obywatela do zdania sobie sprawy z tego, kim jest - prostym zjadaczem chleba, ślepym i głuchym na czyste piękno, niezdolnym do przyjęcia sakramentu nowej sztu$\mathrm{ki}^{38}$.

W eseju na temat poezji Ortega dokładniej wyjaśnia, czym w ogóle jest sztuka $^{39}$. Przede wszystkim, twierdzi, aktywnością, która ma wprowadzać człowieka w wyższe stany świadomości.

Sztuka ratuje nas - jak twierdził Schopenhauer - przed świadomością indywidualną, w której normalnie żyjemy, a która zmusza nas do postrzegania prze-

37 Tenże, Dehumanizacja sztuki, s. 281.

38 Tamże.

${ }^{39}$ Tenże, Poezja nowa, poezja stara, [w:] tegoż, Dehumanizacja sztuki, s. 40. 
mijania zjawisk, narodzin i śmierci rzeczy, powstawania pożądań i niemożność ich zaspokojenia ${ }^{40}$.

Dzięki sztuce uzyskujemy więc możliwość kontemplacji wyższych stanów ducha. Pozwala nam to na zerwanie $\mathrm{z}$ własnym jednostkowym bytem i daje możliwość wzniesienia się na poziom ducha uniwersalnego. Sztuka jako efekt witalnego ducha daje także możliwość zakomunikowania czegoś, czego nie da się wyrazić w żaden inny sposób ${ }^{41}$. W dalszej części rozprawki pada stwierdzenie:

Sztuka jest szlachetnym substytutem życia. Gdybyśmy wszyscy mogli prowadzić życie tak intensywne, pełne wielkich namiętności, szlachetnych melancholii i wszystkich tych uczuć i wrażeń, jakimi przesycone są dramaty Szekspira, to być może moglibyśmy się obejść bez sztuki ${ }^{42}$.

Fragment ten doskonale ilustruje zadanie, jakie według Ortegi ma do spełnienia sztuka w ogóle. Ma ona pobudzać odbiorcę do silnych wzruszeń i potęgować jego uczucia. $\mathrm{Z}$ drugiej strony, jak zauważyliśmy, jej celem jest tworzenie nowych światów, które mają stać się substytutem świata zastanego. Daje każdemu z nas szansę na ucieczkę od codziennej rzeczywistości.

Sztuka przychodzi nam z pomocą, gdy odczuwamy w naszym życiu pustkę, w takim momencie zadaniem sztuki jest „uskrzydlać naszą wyobraźnię $e^{43}$.

Jednym z zadań sztuk plastycznych jest budowanie współistnienia rzeczy w przestrzeni. Artysta może to osiągnąć jedynie dzięki instrumentowi, jakim jest odwzorowanie światła ${ }^{44}$.

Mimo swego humanizmu Ortega nie zapomina, że malarstwo to efekt zamiaru człowieka. Dziełem plastycznym nie może być plama lub zaciek na murze. Gdy hiszpański estetyk pisze, że dzieło sztuki malarskiej zawiera w sobie utrwalone zachowanie, ma na myśli, że w każdym pociągnięciu pędzla malarz utrwala zachowanie charakterystyczne dla niego samego. Każ-

40 Tamże.

${ }^{41}$ R. Gaj, dz. cyt., s. 137.

${ }^{42}$ J. Ortega y Gasset, Poezja nowa, poezja stara, s. 41.

${ }^{43}$ Tamże, s. 42.

${ }^{44}$ Tenże, Adam w raju, s. 65: Budowa koegzystencji, przestrzeni, wymaga posiadania instrumentu jednoczącego, który by był zdolny zmienić się na niezliczone sposoby, nie przestając jednak być jednym i tym samym. W malarstwie ta materia dominująca jest światło. [...] Malarstwo jest kategoriq światła. 
de dotknięcie pędzlem płótna następuje na skutek poruszenia dłonią. Poruszenie to jest zaś efektem pewnego zamysłu. Każdemu działaniu artysty towarzyszy także wolna wola, nadająca jego działaniu sens. W ten sposób na przedmiocie tworzy się znak intencji. W koncepcji Ortegi ma on charakter semantyczny, bo malarstwo, podobnie jak muzyka czy poezja dają możliwość komunikowania się.

Słowo każe nam patrzeć na malarstwo jak na ciągły dialog między artystą i widzem, kiedy jednak do niego dochodzi, słowo staje się zwadą ${ }^{45}$.

Malarstwo jako jeden ze sposobów komunikowania się jest oczywiście w pierwszym rzędzie pewną próbą nawiązania dialogu między artystą a odbiorcą. Można powiedzieć, że obraz jest jak słowo, które przekazuje ideę i zamysł, a z drugiej strony milczenie, zdolne wyrazić te idee, których nie da się wyrazić słowami. Oznacza to, że przez obraz komunikacja staje się możliwa tam, gdzie kończą się możliwości języka.

Filozof zwraca tu uwagę na zagadkowy charakter sztuki malarskiej. Każda z następujących po sobie epok odkrywała w płótnach Velazqueza nowe treści. Błędem poprzednich pokoleń było przekonanie, że zawartych w dziele sztuki treści nie da się jednoznacznie odczytać. Według Ortegi analizując obraz, powinniśmy wyjść z założenia, że on jest jedynie „skamieliną, w której utrwalił się fragment czyjegoś życia"46. Działalność artysty polegająca na nakładaniu na płótno farby stanowi efekt podjętej wcześniej decyzji, która dokonała się w określonym akcie. Aby zrozumieć, czym jest malarstwo, musimy więc odtworzyć krok po kroku sposób widzenia malarza, a nie jak się powszechnie uważa widzenie malarstwa. Należy odkryć intencje kierujące artystą w chwili, gdy przystępował do pokrywania farbą płótna. Niezwykle ważne jest też, co właściwie artysta chciał namalować. Ale według Gasseta mimo wszystko było to sprawą drugorzędną w stosunku do tego, jak chciał to zrobićc ${ }^{47}$.

W tym miejscu Ortega formułuje dwa zgoła odmienne, dotyczące sztuki malarskiej prawa. Pierwsze $\mathrm{z}$ nich to prawo nadmiaru, drugie - prawo niepełni. To ostatnie dotyczy faktu, że obraz nigdy w całości nie zawrze w sobie obecnej w intencji twórcy wypowiedzi. Zawsze będzie niedomówieniem, zagadką, hieroglifem. $Z$ drugiej strony obraz zawiera też w sobie więcej, niż

\footnotetext{
${ }^{45}$ Szerzej na temat relacji słowo-poezja-muzyka w: Poezja nowa, poezja stara, s. 39-41.

${ }^{46}$ Tamże, s. 57.

47 Tenże, Adam w raju, s. 69.
} 
artysta chciał przekazać, zwłaszcza jego intencje, których utrwalania twórca być może nie był świadomy. W kontekście semantyki hiszpański filozof pisze, że: „zawsze będzie jakaś nierównowaga między tym, co nosiliśmy w myślach, a tym, co rzeczywiście powiedzieliśmy"48. Każdy obraz zbudowany jest ze słów „przemilczanych”, czyli takich, które są dla malarza oczywiste. Każdy obraz powstaje też w obrębie jakiegoś stylu w danym czasie panującego, preferowanego przez artystę. „Style są dynamicznymi wirami, które wnoszą do świata nowość, idealnie rozszerzając wszechświat"49. Ów styl rozpoznawalny jest chociażby w pociągnięciach pędzla artysty. Ortega krytykuje jednak stanowiska utrzymujące jakoby artysta był tylko reprezentantem swoich czasów.

Nasza zależność ma zarówno wymiar pozytywny, jak i negatywny; coś aprobujemy i czemuś się sprzeciwiamy. [...] Aby zrozumieć Velazqueza, trzeba być bardzo czujnym właśnie w tej kwestii, gdyż - jak zobaczymy - jego sztuka była nieustanną walką z własną epoką ${ }^{50}$.

W innym artykule filozof zawraca uwagę na to, czym jest w ogóle postęp $\mathrm{w}$ sztuce i w życiu. W powszechnym przekonaniu utożsamiany jest on $\mathrm{z}$ kumulacją idei i rzeczy ${ }^{51}$. Ze wzmiankowanego fragmentu artykułu można jednak wywnioskować, że charakteryzuje go przede wszystkim umiejętność dostrzegania pewnych, jak się wyraża Ortega, „tajemnic”, które uchodzą uwadze przeciętnego człowieka. W opinii Ortegi sztuka malarska ta zdolność do szczególnego postrzegania wynika ze specjalnych własności zmysłu wzroku, który u geniuszy artystycznych odznacza się znamienną ostrością i wrażliwością. Genialni artyści podejmują podobne problemy co zwykli twórcy, ale jak pisze Gasset: „potrafią te tematy odrzeć z niepotrzebnej i ordynarnej skorupy, jaką pokryli ją artyści marni”"52.

Rewolucja artystyczna, jakiej dokonał Velazquez, porównywana jest przez Ortegę do tej, którą w dziedzinie myśli racjonalnej dokonał Kartezjusz, Hume czy Kant ${ }^{53}$. Hiszpański filozof zwraca tu uwage na psychologiczny wymiar tworzenia obrazów. Przed ową rewolucją źrenica malarza skupiała się na każdym przedmiocie $\mathrm{z}$ osobna, co znaczy, że malował przedmioty jakby były

\footnotetext{
48 Tenże, Poezja nowa, poezja stara, s. 58.

${ }^{49}$ R. Gaj, dz.cyt., s. 221.

${ }^{50}$ J. Ortega y Gasset, Velazquez i Goya, s. 61.

${ }^{51}$ Tenże, Trzy obrazy z winem, [w:] tegoż, Dehumanizacja sztuki, s. 73.

52 Tamże.

${ }^{53}$ Tenże, O punkcie widzenia w sztuce, s. 249.
} 
one widziane w odrębnych aktach percepcji. Rewolucja Velazqueza polega zaś między innymi na tym, że wprowadził on jednolity punkt spojrzenia na scenę, dzięki czemu przedmioty chwytane są przez obserwatora jednocześnie, $\mathrm{w}$ tym samym akcie percepcji.

Źrenica artysty tkwi nieruchoma w centrum plastycznego kosmosu, a formy i kształty przedmiotów krążą wokół niej ${ }^{54}$.

Ten skomplikowany sposób widzenia Ortega opisuje bardzo szczegółowo. Dla naszych potrzeb ograniczę się do opisu skrótowego.

Jeżeli rozmieścimy przed nami szereg przedmiotów i wybierzemy jeden, który usytuujemy w centrum sceny obrazu, to na tle reszty obiektów będziemy go postrzegać jasno i wyraźnie, pozostałe pozostaną w obszarze umykającym naszej uwadze. Upraszczając, można byłoby powiedzieć, że obszar ów będzie stanowił tło dla głównego przedmiotu w centrum. Owo tło będzie się jawić jako zamglone, niekształtne, sprowadzone do masy bezforemnych kolorów. Taka, według Ortegi, staje się sceneria obrazu widziana z bliska. Oznacza to, że wyróżniony przedmiot wybija się z tła pozostałych przedmiotów usytuowanych za nim. „Jest bohaterem stojącym w otoczeniu kosmicznych chórów, ponad masą plebsu" 55 . Taki punkt widzenia charakteryzuje nie tylko optyczność, ale i dotykowość, przedmioty stają się dla nas cięższe w zależności od swojej masy lub lżejsze. Inny charakter ma spojrzenie z dystansu. Brak tu już wyróżnionych przedmiotów. Wszystkie zachowują jednolitą hierarchię. Wzrok obserwatora może swobodnie poruszać się po linii horyzontu, nie skupiając na niczym uwagi. „Żaden przedmiot nie ma ostro zarysowanych konturów, wszystko jest tłem, zamazanym i jakby nieformalnym"56.

Na podstawie różnicy spojrzenia bliskiego i dalekiego Ortega buduje swoją teorię zmian, wyjaśniającą ewolucję, która następowała w sztuce nowożytnej, aż do czasów współczesnych. Zmiany, jakie zachodziły na przestrzeni wieków, według filozofa, wynikały z „odchodzenia od tego, co dalekie-, choć bliskie-, ku temu, co leży w bezpośredniej bliskości oka"57. W dalszej części artykułu Ortega dokładniej wskazuje, jakim to konkretnym zmianom, gdyby spojrzeć z perspektywy, ulegało malarstwo zachodnioeuropejskie, począw-

\footnotetext{
${ }^{54}$ Tamże.

55 Tamże, s. 240.

56 Tamże.

57 Tamże, s. 243.
} 
szy od czasów quattrocenta. Uprawiano wówczas malarstwo ciała i bryły, a przedmioty przedstawiano $\mathrm{w}$ taki sposób, aby odzwierciedlały swoją materialność, namacalność. Tym, co najważniejsze i co najbardziej odróżnia to malarstwo od późniejszego, jest fakt, że nie akcentuje się w nim zbyt ostro odmienności w traktowaniu przedmiotów na pierwszym i na dalszym planie. Jedyne, co wyróżnia przedmioty występujące na różnych planach, jest ich wielkość. Malarz był w tym czasie analitykiem. Stawiał sobie pytanie: jakie elementy naturalnego postrzeżenia powinny zostać przeniesione na płótno. Przedmioty malował w różnych perspektywach, jednakową uwagę skupiał na każdym z nich, ukazując bogactwo szczegółów. Według Ortegi nastawienie takie można powiązać z panującą ówcześnie filozofią, która próbowała tworzyć konceptualne modele konstrukcji świata jako jedni składającej się z poszczególnych części. Ortega zwraca uwagę na to, że w tym czasie uznawano w filozofii, iż „skończoną rzeczywistością są substancje indywidualne" ${ }^{58}$.

Inaczej postępował malarz renesansu. Nie odnajdujemy już u niego takiego bogactwa punktów widzenia. Podstawową cechą obrazu staje się całość, „są w nim już zarodki racjonalnej jedności”. Pod ową racjonalną jednością kryje się zasada, którą można uznać za podstawę abstrakcyjnej kompozycji, często stosowanej w renesansie u Rafaela czy Leonarda da Vinci. Analogiczną ideę można znaleźć w racjonalnej filozofii Kartezjusza. „Dla Kartezjusza rzeczywistością jest przestrzeń, tak jak dla Velazqueza była nią wklęsłość" 59 . Zmiana sposobu widzenia następuje u Wenecjan, w dziełach których dominuje niepokój i podniecenie. Według Ortegi „czują nadchodzącą epokę wklęsłości, ale jeszcze nie całkiem sobie $\mathrm{z}$ tego zdają sprawę" ${ }^{\text {" }}$.

$\mathrm{U}$ artystów weneckich punkt postrzegania rzeczy zawartych w scenie obrazu usytuowany jest daleko poza jego powierzchnią. Analityczny sposób widzenia ustępuje tu miejsca postrzeganiu przedmiotów jako elementów pozbawionych swojej materialności. Materialność zaś jako istotny czynnik kształtujący odbiór obrazu staje się szczególnie istotna u malarzy światłocienia, gdzie sposób przedstawienia fenomenu światła jest „radykalną nowością”. Światło stanowi pierwotny czynnik, dzięki któremu przedmioty (oddane jako trójwymiarowe bryły) mogą w ogóle w obrazie zaistnieć. Nie jest to już abstrakcyjna zasada, jak to było w przypadku malarzy renesansowych. „Malarz zostaje zmuszony do widzenia całości swego dzieła zanurzonego w świetle”.

\footnotetext{
58 Tamże, s. 255.

59 Tamże, s. 256.

60 Tamże, s. 246.
} 
Konsekwencję zmian, mających swe źródło właśnie u Velazqueza, widzimy wyraźnie w dziełach impresjonistów. To jego odkryciom zawdzięczają oni tak zwane widzenie wklęsłości rozumiane jako przenikanie przedmiotów w głąb, a nie tylko prezentację ich usytuowania w przestrzeni poprzez różną wielkość geometryczną.

Postępujące odrealnienie świata, które się zaczęło w okresie Odrodzenia, znajduje swoje najdalsze konsekwencje w radykalnym sensualizmie Avenariusa i Macha ${ }^{61}$.

Impresjoniści wykorzystują i modyfikują tę ideę:

Głębokie tło wklęsłości Velazqueza zostaje ściągnięte na pierwszy plan, a tym samym przestaje być tłem ze względu na brak punktu odniesienia ${ }^{62}$.

Przedmioty jawią się tu jako zatarte, ich materialność przestaje odgrywać istotną rolę. Odtwarzanym przedmiotem staje się samo widzenie. Sztuka zaczyna wkraczać na nieznane dotychczas obszary. Artysta odkrywa coś, co do tej pory pozostawało $\mathrm{w}$ cieniu zainteresowań sztuk pięknych, ale poniekąd również filozofów - widzenie. Przedmiot zostaje zastąpiony impresją stanowiącą podstawę przestrzenności obrazu, którą widz musi odkryć, bo inaczej nie zrozumie jego przesłania. Malarz interesuje się zjawiskami dotyczącymi istoty samego procesu postrzegania. Jest to jeden z pierwszych kroków dokonanych $\mathrm{w}$ ramach procesu internalizacji. Jednym $\mathrm{z}$ wielu dalszych stanie się malarstwo Cezanne’a, który bryły traktuje jako twory wyobraźni: „Cezanne powiada: sztuka to realizowanie. Ja mówię: sztuka to indywidualizacja" ${ }^{63}$. Artysta nawiązuje kontakt $\mathrm{z}$ rzeczywistością jedynie $\mathrm{w}$ sensie metaforycznym. Inspiruje się bryłami, ale kształtuje je na płótnie zgodnie z narzuconą przez samego siebie zasadą odtwarzającą jedynie idee. Zaczyna projektować przedmioty, które maluje:

[...] oczy, zamiast chłonąć rzeczy z zewnątrz, zmieniły się teraz w projektory krajobrazów i fauny zasiedlającej ludzkie wnętrze. Przedtem były zbiornikami

\footnotetext{
${ }^{61}$ Tamże.

${ }^{62}$ Tenże, O punkcie widzenia $w$ sztuce, s. 252.

${ }^{63}$ Tenże, Adam w Raju, s. 63.
} 
absorbującymi świat rzeczywisty, a teraz bije z nich na zewnątrz źródło nierzeczywistości ${ }^{64}$.

Podsumowując dzieje malarstwa, Ortega zwraca uwagę na trzy etapy mające duży wpływ na sztukę współczesną. Pierwszym z nich jest „odwzorowywanie" rzeczy, w ramach którego artysta poświęcał się malowaniu rzeczywistości zewnętrznej wobec podmiotu. Kolejnym było malowanie wrażeń jako czysto subiektywnych zjawisk doznawanych przez podmiot, a w konsekwencji uprzedmiotawianie idei jako bytów intersubiektywnych. Całość można podsumować fragmentem $\mathrm{z}$ samego Ortegi:

Tak więc istnieją malarze, którzy malują rzeczy, jak również malarze, którzy posługując się malowanymi przez siebie rzeczami, tworzą obrazy ${ }^{65}$.

Do tych drugich z pewnością można zaliczyć Velazqueza, El Greca, ale także pokolenia malarzy późniejszych, impresjonistów czy kubistów.

Refleksje Gasseta dotyczą także samej natury estetyki.

Miłośnicy sztuki żywią zazwyczaj niechęć wobec estetyki [...] Estetyka dąży do osiodłania grzbietu niespokojnego Pegaza, starając się poszufladkować pojęciowo niewyczerpalną obfitość treści artystycznych ${ }^{66}$.

W innym fragmencie możemy przeczytać: „W estetyce zawsze po pracochłonnym zamykaniu kufra okazuje się, że czegoś zapomnieliśmy, trzeba go na nowo otworzyć, potem znowu zamknąć" ${ }^{67}$. W tych metaforycznych słowach Ortega $z$ jednej strony wskazuje na niewyczerpywalność pola możliwych problemów estetyki, z drugiej zaś ukazuje jej wtórny charakter wobec samego aktu twórczości artystycznej. Jednak w konsekwencji hiszpański filozof rehabilituje jej pozornie zdewaluowane wartości, pisząc: „estetyka warta jest tyle samo, co dzieło sztuki”" ${ }^{68}$.

Refleksje dotyczące natury piękna Ortega zawarł w eseju, którego przedmiotem stał się angielski poeta i pisarz Ruskin. Odwołując się do popularnego niegdyś, a zrozumiałego dziś pojęcia „przemysł artystyczny”, pisze, że dekora-

\footnotetext{
${ }^{64}$ Tenże, O punkcie widzenia w sztuce, s. 254.

${ }^{65}$ Tenże, Adam w raju, s. 47.

${ }^{66}$ Tamże, s. 51.

67 Tamże.

${ }^{68}$ Tamże, s. 52.
} 
cja nie jest jedynym występującym w ludzkim świecie przeznaczeniem piękna. Użyteczność nie wyjaśnia wszystkich jego aspektów, jest ono ,jak woda $\mathrm{z}$ domieszką wina" ${ }^{69}$. Według Ortegi, by zrozumieć piękno, należy wyzwolić je $\mathrm{z}$ „dekoracyjnego przebrania”. Jak już zostało wyżej przypomniane, sztuka ma wyrażać to, czego nie da się wyrazić w inny sposób, ale ma ona też przedstawiać rzeczywistość, która zaistniała wcześniej jako idea artysty. Jednym z narzędzi na drodze do przedstawiania nowych światów staje się metafora, a przewodnikiem na tej drodze uczucie estetyczne. Uczucie owo jest sposobem ekspresji, który umożliwia dokonanie się tego, co miało być wyrażone. Wędrówkę po przywołanej w roli metafory drodze można rozumieć jako proces, który nigdy się nie kończy. Powstałe dzieło sztuki istniejąc przez kilka wieków, wciąż wzbudza u kolejnych pokoleń odbiorców uczucia estetyczne.

Don Kichot nie jest moim uczuciem ani realną osobą czy obrazem osoby prawdziwej: jest nowym obiektem, który żyje w przestrzeni świata estetycznego, różnego od świata fizycznego i psychologicznego ${ }^{70}$.

Konsekwencją tej koncepcji jest stwierdzenie, że sztuka nie jest ani realnością, ani idealizacją, lecz irrealizacją już ze swej natury. Wynika z tego, że dzieło sztuki nie jest realnością, gdyż ma zdolność tworzenia bytów nierealnych. Z drugiej strony dysponuje zdolnością do rozkładania rzeczywistości na czynniki pojedyncze: „tak świat piękna zaczyna się na krańcach świata realnego" 71 .

Celem każdego artysty staje się w tym ujęciu rozbicie zastanej rzeczywistości, jej uczuciowa interpretacja oraz obdarzenie życiem wiecznym ${ }^{72}$. Ważną rolę pełni tu pojęcie stylu, który „[...] w świecie estetycznym jest jedynie słowem, ręką i źrenicą, tylko w nim i poprzez niego możemy dotrzeć do wiedzy o pewnych nowych stworzeniach"73. Każdy ze stylów odznacza się własną specyfiką. Ma odrębny język, posługuje się odmiennymi narzędziami, ale

${ }^{69}$ R. Gaj, dz. cyt., s. 222.

70 Tamże, s. 236.

${ }^{71}$ Tamże, s. 237.

${ }^{72}$ J. Ortega y Gasset, Adam w raju, s. 70: Namalować, to znaczy obdarzyć to możliwościa życia wiecznego. Wyobraźmy sobie, że stoimy przed modnym dziełem sztuki. Przedstawione postacie pobudzają nasza fantazję, poruszają nas, żyją dla nas. Nie minie pięćdziesiąt lat, a oczom naszych dzieci postacie te ukaża się zmienione, nieruchome, martwe. Dlaczego teraz umarły? Czym żyly przedtem? Żyły dzięki nam, dzięki naszym uczuciom - chwilowym, ubocznym i ulotnym.

${ }^{73}$ R. Gaj, dz. cyt., s. 238. 
tylko dzięki temu możliwe jest poznanie bytów artystycznych, jakie tworzy artysta.

Dokonując ogólnej refleksji nad myślą estetyczną Ortegi y Gasseta, możemy stwierdzić, że jego poglądy nie stanowiły jakiegoś jednolitego, spójnego systemu. Docierając do istoty tekstów hiszpańskiego myśliciela, niejednokrotnie trzeba nie tylko sięgnąć do książek, które publikował, ale także przewertować czasopisma polityczne, w których również często zabierał głos. Jego poglądy zostały wyłożone w sposób chaotyczny. Teksty, które publikował w okresie młodzieńczym, nierzadko były preludium do tematu rozwiniętego potem w okresie dojrzałości duchowej, po odbytych podróżach do Niemiec czy Francji.

Można trywialnie powiedzieć, że Ortega miał szerokie zainteresowania. Jego filozofia charakteryzuje się wielowątkowością. Zajmował się podmiotem poznania, budował własną koncepcję geniuszu, interesował się zarówno samym procesem poznania, jak i jego przedmiotem. Jak pisze Stanisław Cichowicz we wstępie do Dehumanizacji sztuki:

Ortega był mistrzem eseju i intelektualizacja literatury hiszpańskiej, którą właśnie pokolenie 1898 zapoczątkowało, osiągnęła dzięki niemu swoje apogeum; był mistrzem eseju, bo na kilku stronach umiał zawrzeć wszystko ${ }^{74}$.

Często, pisząc jakiś artykuł, dotykał najróżniejszych sfer szeroko pojętego życia duchowego od polityki przez kulturę do etyki. Można przewrotnie stwierdzić, że zawsze zainteresowany był „całością”, którą rozpatrywał w jej związku z „częścią”. Problemem utrudniającym pełne zrozumienie tekstów Gasseta jest także ich niedostępność po polsku, gdyż tylko niewielka część ogromnego dorobku wielkiego hiszpańskiego humanisty została jak do tej pory przetłumaczona na nasz język. Celem nigdy nie było dla niego budowanie abstrakcyjnych systemów, lecz, z drugiej strony, jego obycie z filozofią europejską powodowało, że jako jeden z niewielu Hiszpanów zwrócił uwagę swoich rodaków na bogatą spuściznę tej filozofii. Krytycy i badacze stawiają go u boku takich wielkich filozofów hiszpańskich jak Suarez, Balmes, Sanz del Rio, nadając jednak jego myśli szczególną rangę.

${ }^{74}$ S. Cichowicz, Wstęp, [do:] J. Ortega y Gasset, Dehumanizacja sztuki, s. 10. 


\section{Abstract \\ Theory of fine arts of Ortega y Gasset}

In my essay I would like to rehabilitate the importance of the spanish philosophy and indicate its important position in the twentieth century with particular emphasis on the theory of fine arts - what particularly interests me. I would also like to draw attention to the method, which Ortega uses in research on art - referring object to life. However, if Ortega y Gasset has exhausted the research on the matter of art?

If he philosopher is consistent in his research? These problems take my analysis of works of Jose Ortega y Gasset. obstacle in the studies Gasset's thought in Poland is the unavailability of polish translations, in the Polish language was published only a small part of the books of the philosopher. On one hand, Gasset's thought is a perfect example of spanish philosophy, philosopher to the everyday life of their country, does not create abstract systems, refers. On the other hand Ortega y Gasset's familiarity with the european philosophy allowed him as one of the few to open the minds of his countrymen on the rich heritage of European thought 